УДК 631.5:633.854.79"321":631.8

(C) 2016

Срмакова Л. М., кандидат сільськогосподарських наук,

Пророченко Т. I., аспірант

(науковий керівник - кандидат сільськогосподарських наук Л. М. Срмакова)

Національний університет біоресурсів і природокористування України

\title{
ТРИВАЛІСТЬ МІЖФАЗНИХ ПЕРІОДІВ РІПАКУ ЯРОГО ЗАЛЕЖНО ВІД УДОБРЕННЯ В УМОВАХ ПРАВОБЕРЕЖНОГО ЛІСОСТЕПУ УКРАЇНИ
}

\section{Рецензент - доктор сільськогосподарських наук Ю. П. Манько}

Відображено вплив елементів інтенсифікації вирошування на тривалість проходження міжфазних періодів ріпаку ярого в умовах Правобережного Лісостепу. Відмічено, щзо вивчені в досліді фактори сприяли різному за тривалістю проходженню фаз росту та розвитку рослин ріпаку. За результатами проведених досліджень з'ясовано, щу в разі внесення азотних мінеральних добрив період вететаиії збільшувався в усіх варіантах, проте залежав від виду добрив. У свою чергу на тривалість періоду вететації досліджуваних сортів та гібридів ріпаку ярого вплинули $i$ погодні умови років проведення досліджень. Встановлено, щзо оптимізація режиму живлення за рахунок внесення різних видів азотних добрив (аміачна селітра, сульфат амонію, карбамід) забезпечує більи повну реалізацію потенціалу продуктивності рослин.

Ключові слова: удобрення, сорт, гібрид, період вететації, міжфазні періоди.

Постановка проблеми. Важливість такої сільськогосподарської культури як ріпак у світі не зменшується. Популярність ріпаку в Україні, що протягом декількох останніх років пішла на спад, не зменшує значення цієї культури.

Експерти сільського господарства прогнозують зростання попиту на ріпак ярий нинішнього сезону в усьому світі і в Україні зокрема. Для цього є дві суттєві причини: по-перше, значне вимерзання ріпаку озимого; по-друге, зменшення площ посіву. Однією з причин низької реалізації потенціалу продуктивності нових високопродуктивних сортів та гібридів ріпаку ярого $\epsilon$ відсутність чітко розроблених зональних технологій вирощування. Крім того, у виробництві часто не дотримуються технології вирощування ріпаку ярого, що обумовлено пошуком джерел зменшення витрат на виробництво. Як наслідок, це зумовлює необхідність проведення наукових досліджень 3 метою з'ясування впливу агрометеорологічних факторів на процеси росту і розвитку рослин ріпаку ярого та інтенсифікації елементів технології вирощування [2].

Науково обгрунтована система удобрення головний чинник формування високоврожайних посівів. Серед елементів інтенсифікації вирощування вплив добрив на продуктивність рослин досягає 50-60\% і більше. Ріпак потребує більшої кількості добрив, ніж зернові культури. Орієнтовно 10-30\% елементів живлення (залежно від рівня врожайності) ріпак може засвоїти 3 грунтових запасів. Решту потреби забезпечують мінеральними та органічними добривами [5].

Найбільше ріпак реагує на азотні добрива. Азот - це основний елемент для росту рослин [6]. Він $€$ важливою складовою хлорофілу, речовини, що надає рослинам зеленого кольору. Азот досить мобільний елемент та може легко вимиватися 3 грунту. Тому його слід регулярно поповнювати для підтримки росту рослин. 3 метою оптимізації азотного живлення рослин їх доцільно вносити у два прийоми: до початку сівби та у підживлення.

У системі удобрення важливим $є$ вибір форми азоту та відповідного виду азотних добрив. Для удобрення ріпаку ярого переважно використовують такі види:

- аміачна селітра $\left(\mathrm{NH}_{4} \mathrm{NO}_{3}\right)$ - універсальне, багате на азот добриво. Використовується на будьякому типі грунту та $є$ найефективнішим у підживленні;

- сульфат амонію $\left(\left(\mathrm{NH}_{4}\right)_{2} \mathrm{SO}_{4}\right)$ - амонійна форма азоту, краще засвоюється рослинами, ніж нітратна. Підкислюючі грунт властивості цього добрива створюють відмінне поживне середовище для всіх рослин родини капустяних;

- карбамід $\left(\left(\mathrm{NH}_{2}\right)_{2} \mathrm{CO}\right)$ - 3 усіх азотних добрив відрізняється найбільшим вмістом азоту - $46 \%$. Перевагою його перед аміачною селітрою $\epsilon$ те, що азот краще утримується грунтом і не так легко вимивається грунтовими водами.

У процесі онтогенезу ріпак, як і більшість сільськогосподарських квіткових культур, проходить 12 етапів росту і розвитку. Водночас утворюються нові органи, збільшуються їх розміри, відбувається зміна фізіолого-біохімічних процесів i, як наслідок, змінюються вимоги до зовнішнього середовища [3].

Фенологія рослин ріпаку ярого характеризуєть- 


\section{СІЛЬСЬКЕ ГОСПОДАРСТВО. РОСЛИННИЦТВО}

ся тривалістю проходження фізіологічних фаз: сходи, стеблування, бутонізація, цвітіння, плодоутворення та достигання насіння. Про настання кожного $з$ цих етапів розвитку можна говорити в разі візуалізації таких ознак: сходи визначаються появою сім'ядольних листків; стеблування - утворенням пагона з бутонами на верхівці; бутонізація настає в разі підняття бутонів стебла над верхніми листками; початок цвітіння характеризується появою квіток в основі суцвіття; повне цвітіння (70-80 \%) - утворенням у нижній частині суцвіття перших стручків; кінець цвітіння визначається заповненням суцвіття стручками, при цьому цвіте 10-15 \% квіток; плодоутворення відбувається практично в межах періоду цвітіння; дозрівання насіння починається 3 моменту набуття ним світло-зеленого забарвлення (70\% вологості), потім воно зеленіє (60\% вологості) i в напівтехнічному (50\% вологості) стані має матово-зелене або жовте забарвлення; технічна стиглість настає за побуріння 70 \% стручків, насіння стає кулястим, великим і під час розтирання розпадається на половинки [1]. На тривалість міжфазних періодів ріпаку ярого впливають різні поєднання технологічних елементів та погоднокліматичних умов, що змінюються в процесі онтогенезу.

Аналіз останніх досліджень і публікацій, у яких започатковано розв'язання проблеми. Ріпак ярий відноситься до культур інтенсивного типу живлення, тому реалізація біологічного потенціалу його в значній мірі визначається застосуванням добрив у необхідній кількості та оптимальним співвідношенням окремих елементів живлення. Особливо вимогливий ріпак до азотного живлення і загальна потреба його в азоті становить 60-120 кг/га для забезпечення врожайності насіння на рівні 2 т/га. Тому в таких умовах актуальним $\epsilon$ вирішення питання оптимізації азотного живлення рослин.

Питаннями оптимізації технології вирощування, селекції та факторів, що впливають на ріст, розвиток та формування продуктивності ріпаку ярого займалися в різні роки такі вчені: В. Д. Гайдаш, І. Л. Марков, М. Г. Гусєв, Ю. А. Утеуш, О. Ф. Антоненко, І. Д. Ситник, Б. К. Доун, В. В. Лихочвор та інші $[3,4]$.

Метою дослідження було вивчення впливу різних видів азотних добрив на тривалість проходження міжфазних періодів сортів та гібридів ріпаку ярого в умовах Правобережного Лісостепу України.

Матеріали і методика досліджень. Для вирішення поставлених завдань протягом 20152016 рр. нами були проведені польові досліджен- ня в умовах стаціонарної польової сівозміни кафедри рослинництва у ВП НУБіП України «Агрономічна дослідна станція» (Васильківський район, Київська область, с. Пшеничне).

Грунти - чорноземи типові (глибокі) малогумусні, грубопилувато-легкосуглинкового механічного складу. Орний шар має зернистопилувату структуру, а підорний - горіхуватозернисту. За механічним складом маса грунту має $37 \%$ фізичної глини та $63 \%$ - піску. Вміст гумусу в орному шарі становить 4,2-4,6 \%, ємність поглинання - 31-32 мг-екв на 100 г грунту, ступінь насичення основами близько $90 \%$. У шарі грунту 0-20 см міститься 0,2-0,31 \% загального азоту, 0,15-0,25 \% фосфору і 2,3-2,5\% калію. Вміст рухомого фосфору - 4-5,5 мг на 100 г грунту (високий), обмінного калію - 15,0-16,5 мг на 100 г грунту (вище середнього), легкогідролізованого азоту - близько 14-16 мг/100 г (вище середнього). Реакція грунтового розчину близька до нейтральної, $\mathrm{pH}$ сольове 6,7-7,0.

Сівбу проводили сівалками Клен та С3-3,6, формуючи різну ширину міжрядь: 12,5, 15,0, 25,0 та 30,0 см 3 нормою висіву сортів та гібридів 0,8, $1,0,1,2$ та 1,4 млн схожих насінин на гектар.

Дослідження проводилися із сортами Сіріус (контроль), Сріблястий; гібридами Джері та Джером. Мінеральні добрива вносили під основний обробіток грунту, за сівби та у підживлення згідно зі схемою досліджень: 1 - фон $\left(\mathrm{P}_{60} \mathrm{~K}_{90}\right)-$ контроль; 2 - фон $+\mathrm{N}_{90}\left(\mathrm{~N}_{60}+\mathrm{N}_{30}\right)$ аміачна селітра $\mathrm{NH}_{4} \mathrm{NO}_{3} ; 3-ф о н ~+\mathrm{N}_{90}\left(\mathrm{~N}_{60}+\mathrm{N}_{30}\right)$ карбамід $\left(\left(\mathrm{NH}_{2}\right) \mathrm{CO}\right) ; 4-\phi о н+\mathrm{N}_{90}\left(\mathrm{~N}_{60}+\mathrm{N}_{30}\right)$ сульфат амонію $\left(\left(\mathrm{NH}_{4}\right) \mathrm{SO}_{4}\right)$. Площа облікової ділянки $25 \mathrm{~m}^{2}$. Повторність досліду 4-разова.

Результати досліджень. Одним із факторів, що може впливати на тривалість проходження міжфазних періодів ріпаку ярого є удобрення. Зокрема, це стосується забезпеченості рослин азотом. Проведені нами дослідження дали змогу встановити, що тривалість міжфазних періодів у більшій мірі залежала від погодних умов у роки досліджень, ніж від удобрення. Так, у 2015 році термін від сівби до повних сходів досліджуваних сортів та гібридів тривав 8-9 діб і не залежав від удобрення (див. табл.). У 2016 році повні сходи з'явились через 1012 днів. Спостерігався прямий вплив погодних умов на тривалість проходження цього періоду. В першу декаду квітня 2016 року спостерігалось різке потепління до $+18-19{ }^{\circ} \mathrm{C}$, тому сівбу було проведено 7 квітня. В наступні дві декади відмічалось різке зниження температури (у нічний період доби до 3,3-4,4 $\left.{ }^{\circ} \mathrm{C}\right)$. В окремі дні спостерігалися приморозки, що негативно вплинуло на рослини ріпаку ярого, зокрема на тривалість з'явлення повних сходів. 
СІЛЬСЬКЕ ГОСПОДАРСТВО. РОСЛИННИЦТВО

\begin{tabular}{|c|c|c|c|c|c|c|c|}
\hline \multicolumn{8}{|c|}{$\begin{array}{c}\text { Tривалість проходження міжсфазних періодів ріпаку ярого залежно від удобрення, } \\
\text { днів (середнє за 2015-2016 рр.) }\end{array}$} \\
\hline 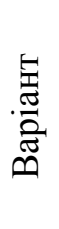 & Рік & $\begin{array}{l}\text { Сходи- } \\
\text { утворення } \\
\text { розетки }\end{array}$ & $\begin{array}{c}\text { Утво- } \\
\text { рення } \\
\text { розетки- } \\
\text { стеблу- } \\
\text { вання }\end{array}$ & $\begin{array}{c}\text { Стеблу- } \\
\text { вання- } \\
\text { бутонізація }\end{array}$ & $\begin{array}{c}\text { Бутонізація- } \\
\text { цвітіння }\end{array}$ & $\begin{array}{l}\text { Цвітіння-- } \\
\text { дозрівання }\end{array}$ & $\begin{array}{c}\text { Період } \\
\text { вегетації }\end{array}$ \\
\hline 1 & 2 & 3 & 4 & 5 & 6 & 7 & 8 \\
\hline \multicolumn{8}{|c|}{ Сорт Cipiyc } \\
\hline \multirow{2}{*}{1} & 2015 & 19 & 12 & 11 & 20 & 33 & 95 \\
\hline & 2016 & 23 & 15 & 13 & 18 & 28 & 97 \\
\hline \multirow{2}{*}{2} & 2015 & 19 & 13 & 13 & 21 & 36 & 102 \\
\hline & 2016 & 21 & 13 & 13 & 20 & 32 & 99 \\
\hline \multirow{2}{*}{3} & 2015 & 19 & 13 & 13 & 21 & 36 & 102 \\
\hline & 2016 & 21 & 13 & 12 & 20 & 32 & 98 \\
\hline \multirow{2}{*}{4} & 2015 & 19 & 13 & 13 & 21 & 36 & 102 \\
\hline & 2016 & 21 & 13 & 12 & 20 & 32 & 98 \\
\hline \multicolumn{8}{|c|}{ Сорт Сріблястий } \\
\hline \multirow{2}{*}{1} & 2015 & 19 & 12 & 11 & 20 & 33 & 95 \\
\hline & 2016 & 23 & 14 & 12 & 17 & 29 & 95 \\
\hline \multirow{2}{*}{2} & 2015 & 19 & 13 & 13 & 21 & 36 & 102 \\
\hline & 2016 & 21 & 13 & 13 & 20 & 32 & 99 \\
\hline \multirow{2}{*}{3} & 2015 & 19 & 13 & 13 & 21 & 36 & 102 \\
\hline & 2016 & 21 & 13 & 13 & 20 & 32 & 99 \\
\hline \multirow{2}{*}{4} & 2015 & 19 & 14 & 13 & 22 & 36 & 104 \\
\hline & 2016 & 21 & 13 & 14 & 20 & 32 & 100 \\
\hline \multicolumn{8}{|c|}{ Гібрид Джері } \\
\hline \multirow{2}{*}{1} & 2015 & 19 & 12 & 11 & 20 & 34 & 96 \\
\hline & 2016 & 22 & 13 & 15 & 18 & 29 & 97 \\
\hline \multirow{2}{*}{2} & 2015 & 19 & 13 & 11 & 21 & 36 & 100 \\
\hline & 2016 & 19 & 12 & 14 & 21 & 32 & 98 \\
\hline \multirow{2}{*}{3} & 2015 & 19 & 12 & 14 & 21 & 33 & 101 \\
\hline & 2016 & 19 & 12 & 14 & 21 & 33 & 99 \\
\hline \multirow{2}{*}{4} & 2015 & 19 & 14 & 12 & 21 & 36 & 102 \\
\hline & 2016 & 19 & 12 & 14 & 21 & 32 & 98 \\
\hline \multicolumn{8}{|c|}{ Гібрид Джером } \\
\hline \multirow{2}{*}{1} & 2015 & 19 & 12 & 13 & 21 & 34 & 99 \\
\hline & 2016 & 22 & 13 & 15 & 18 & 29 & 97 \\
\hline \multirow{2}{*}{2} & 2015 & 19 & 12 & 11 & 21 & 36 & 99 \\
\hline & 2016 & 19 & 12 & 14 & 21 & 32 & 98 \\
\hline \multirow{2}{*}{3} & 2015 & 19 & 13 & 12 & 21 & 36 & 101 \\
\hline & 2016 & 19 & 12 & 14 & 21 & 32 & 98 \\
\hline \multirow{2}{*}{4} & 2015 & 19 & 13 & 13 & 22 & 36 & 103 \\
\hline & 2016 & 19 & 12 & 14 & 21 & 32 & 98 \\
\hline
\end{tabular}

Тривалість міжфазного періоду утворення розетки-стеблування певною мірою залежала від удобрення. Залежно від удобрення та погодних умов років проведення досліджень тривалість міжфазного періоду досліджуваних сортів та гібридів у 2015 мало різнилася, а у 2016 році цей період подовжився на 1-2 дні залежно від гібриду (сорту). 
Copm Cipiyc

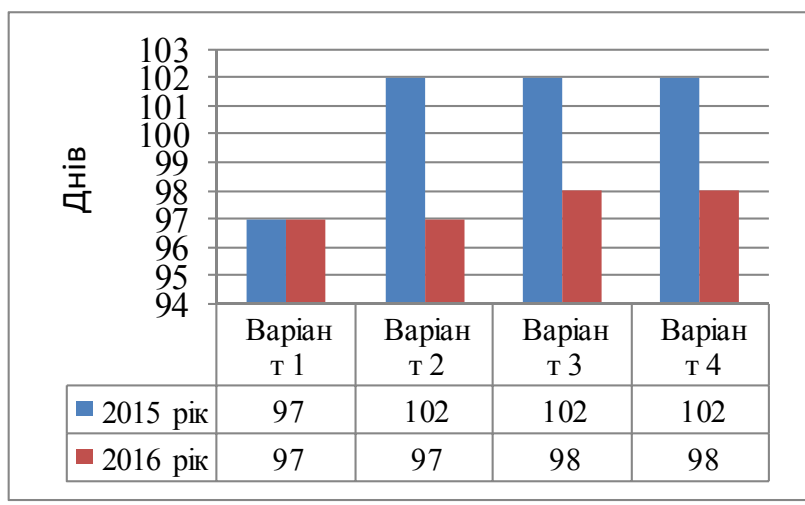

Гібрид Джері

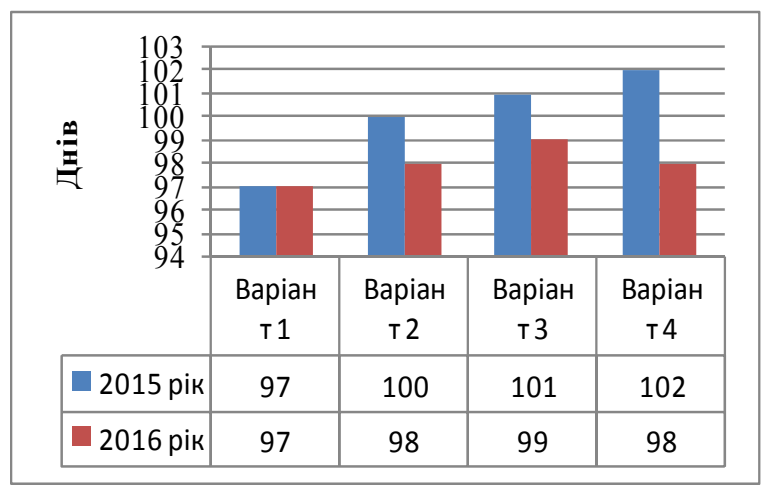

Сорт Сріблястий

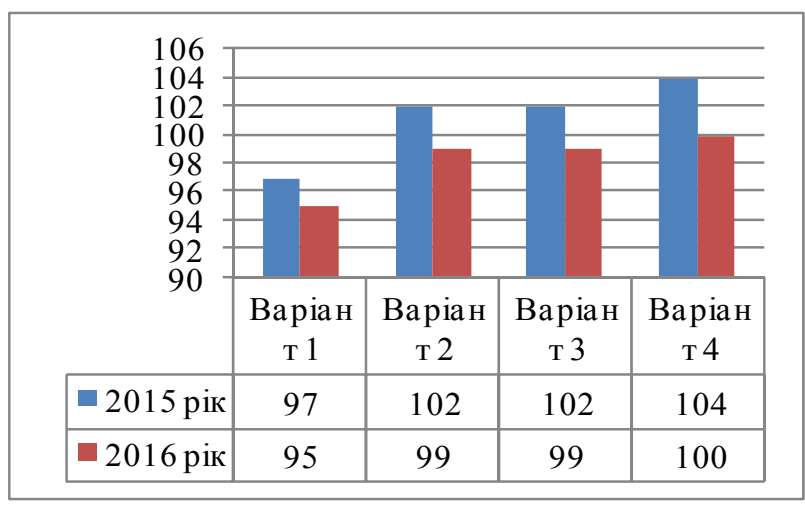

Гібрид Джером

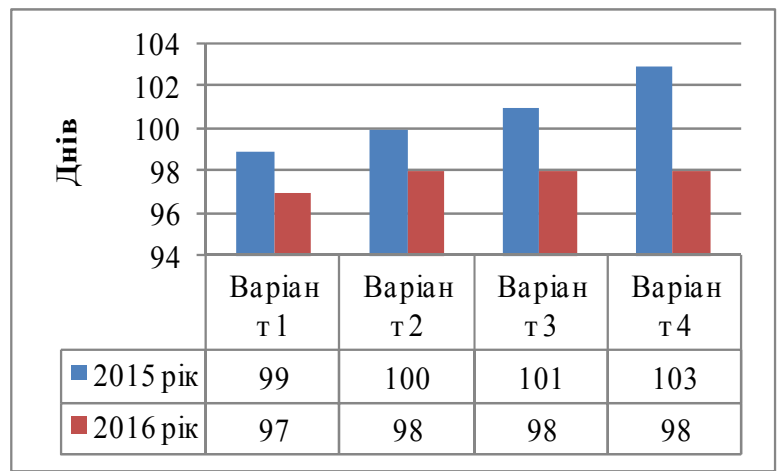

\section{Рис. Тривалість вегетаційного періоду досліджуваних сортів і гібридів ріпаку ярого залежно від удобрення, днів}

Міжфазний період стеблування-бутонізація залежно від удобрення у 2015 році коливався в межах 11-13 днів, у 2016 році змінювався від 12 до 16 діб (на контрольному варіанті).

Встановлено очевидний вплив удобрення і на проходження міжфазного періоду бутонізаціяцвітіння. У 2015 році найбільшим він був у гібрида Джером за варіанту удобрення Фон $+\mathrm{N}_{90}$ $\left(\mathrm{N}_{60}+\mathrm{N}_{30}\right)$ сульфат амонію $\left(\left(\mathrm{NH}_{4}\right)_{2} \mathrm{SO}_{4}\right)$ та становив 22 дні, найменшим - у сортів Сріблястий та Сіріус на контрольному варіанті Фон $-\mathrm{P}_{60} \mathrm{~K}_{90}$ (20 днів).

Тривалість періоду цвітіння-повна стиглість досліджуваних сортів та гібридів у розрізі років змінювалася залежно від удобрення та погодних умов. У 2015 році найбільш тривалим він був за внесення азотних добрив у всіх варіантах і становив 36 днів, найменшим на контролі - 33 дні. У 2016 році погодні умови посприяли тому, що даний міжфазний період був коротшим порівняно 3 попереднім роком. Найбільшим він був у варіантах із внесенням азотних добрив і становив 32 дні, найменшим на контролі - 28 днів.
Тривалість вегетаційного періоду сортів та гібридів ріпаку ярого в роки проведення досліджень різнилася за варіантами (див. рис.).

У середньому за роки проведення досліджень спостерігався вплив удобрення на тривалість проходження міжфазних періодів. Внесення азотних добрив сприяло його збільшенню на 1-5 днів. Аналогічна залежність спостерігалась і від погодних умов та біологічних особливостей досліджуваних сортів (гібридів). Погодні умови 2016 року спричинили зрідження посівів сортів Сіріус та Сріблястий та відповідно зменшення тривалості вегетаційного періоду.

Висновок. Встановлено, що вивчені в досліді фактори по-різному впливали на тривалість проходження фаз росту та розвитку рослин ріпаку ярого. Не зважаючи на те, що період вегетації сортів та гібридів ріпаку ярого збільшувався в усіх варіантах досліду за внесення азотних добрив, виявлена залежність тривалості міжфазних періодів від виду азотних добрив та встановлена перевага застосування сульфату амонію на посівах ріпаку ярого в підживленні. 


\section{БІБЛІОГРАФІЯ}

1. Белик Н. Л. Биологические основы технологий возделывания рапса ярового и редьки масленичной в центральном Черноземье. : автореф. дисс. д.с.-Х.н. / Н. Л. Белик. - М. : Тамбовский госуниверситет им. Г. Р. Державина. $-2003 .-41$ с.

2. Губенко Л. В. Вплив системи удобрення на ріст, розвиток та продуктивність ріпаку ярого // Збірник наукових праць Національного наукового центру «Інституту землеробства УААН» / Л. В. Губенко. - Вип. 3-4. - К., 2007. - С. 99-103.

3. Кляченко О. Л. Озимий та ярий ріпак. Біологія. Селекція. Біотехнологія / Л. О. Кляченко, І. Д. Ситнік, О. К. Гальчинська : монографія. - К. :
Фітосоціоцентр, 2012. - 13 с.

4. Лихочвор В. В. Ріпак / В. В. Лихочвор. Львів : НВФ «Українські технології», 2005. - 82 с.

5. Ніколаєнко Л. О. Роль добрив при вирощуванні ярого ріпаку в умовах північного степу України / Л. О. Ніколаєнко, С. М. Слободян // Перлини степового краю : матеріали I регіон. наук.-практ. агроекол. конф. (1-2 грудня 2005 р.). Миколаїв : МДАУ, 2005. - С. 34-38.

6. Рапс и сурепица (Выращивание, уборка, использование) / [Шпаар Д. и др.] ; под общей редакцией Д. Шпаара. - М. : ИД ООО «DLV АГРОДЕЛО», 2007. - 320 c. 